\title{
"Cue the Sun": Soundings from Millennial Suburbia
}

\author{
Robert Beuka
}

In a crucial scene from Peter Weir's hit 1998 film The Truman Show, protagonist Truman Burbank (Jim Carrey), after discovering that his picture-perfect suburban existence not only seems to be the stuff of TV situation comedy but in fact is so, makes a break for freedom. As Truman attempts to escape his imprisoning soundstage suburban world under the cover of night, his omnipotent foe, the creator/ director of "The Truman Show," Christof (Ed Harris), directs his minions to "cue the sun" and flood the area with sunlight, even though it is the middle of the night. A climactic moment of sorts, Christof's order-and the wee-hours sunrise that follows - makes plain the utter artificiality of Truman's universe, while at the same time highlighting the forces massed to keep Truman in his place. Read metaphorically, this sequence in Weir's film depicts suburbia not only as an artificial reconstruction of small-town America but also, more tellingly, as a landscape of imprisonment and control. And while the conceit of The Truman Show may have been clever (if not, perhaps, entirely original—as fans of Philip K. Dick's 1959 novel Time Out of Joint might argue), its thematic message was by no means unique: indeed, American fiction and films from the past half-century that depict the suburbs have painted a consistently negative portrayal of this environment. Almost without fail, the major novels, stories, and films chronicling suburban life have envisioned suburbia as a contrived, dispiriting, and alienating place. Even today, at a time when

Robert Beuka is Assistant Professor of English at the City University of New York-Bronx Community College. His first book, SuburbiaNation: Reading Suburban Landscape in Twentieth-Century American Fiction and Film, is forthcoming from Palgrave Macmillan. 
more Americans live in the suburbs than either the city or the country, and when the success of "gated communities" and "neo-traditional" towns suggests that the process of suburbanization continues to evolve, the major current films about suburbia (The Truman Show, Gary Ross's Pleasantville, Sam Mendes's American Beauty, and Todd Haynes's Far From Heaven) nonetheless represent this environment as an entrapping and debilitating place to live. I will argue that this consistent focus on suburbia as an American dystopia is more than coincidence, and instead reflects our uneasy relationship to an environment heavily invested with, even defined by, middle-class America's cultural aspirations and anxieties.

A primary factor behind our culture's ambivalent stance toward suburbia is the elusive nature of suburban place identification. For the suburb, in breaking apart the urban/rural binary that had once characterized the American landscape, presents a third term in this equation, a space which remains an enigma even to itself: economically linked to the city, the suburb nevertheless resists urban identification; and if suburbia masquerades as the country, as a sort of plotted, ordered, endlessly repeating pastoral landscape, its calculated, precise parceling of the natural landscape stands in stark contrast to the abiding contours of the rural terrain it continuously supersedes. In this sense, the suburban landscape presents, in the apt phrasing of Terrell Dixon, "a kind of denatured nature . . . shaped for high-end commodification" (80). Moreover, as opposed to the traditional American "small town," the suburb, at least as it is depicted in the major works of suburban fiction and film, is not a singular, specifiable place. Instead, suburbia is most noteworthy for the planned homogeneity of its architecture and landscape. In that regard, one might think of postwar suburban developments as prototypes of what Fredric Jameson calls "postmodern hyperspace," which "has finally succeeded in transcending the capacities of the individual human body to locate itself . . . and cognitively to map its position in a mappable external world" (44). Put another way, the suburb has presented what memoirist D. J. Waldie has termed "the anxiety of the grid": the knowledge that the suburban subdivision lacks its own self-contained sense of place identity and instead "opens outward without limits" to a landscape composed of like grids (118).

Lacking a clear connection to the more knowable terrains of the city, the country, or the small town, the suburb instead has assumed meaning and cultural significance largely through its representations in the popular arts and media. And, as any viewer of Nickelodeon's "TV Land" network can attest, perhaps the most enduring cultural impression of suburbia was cast during the massive wave of postwar suburbanization in the 1950s. Evidence of the lasting power of TV's vision of suburbia can be found in the success of such contemporary films as The Truman Show and Pleasantville, both of which look backward in time to invoke 1950s-style suburban situation comedy as a metaphor for exploring the repressions and assorted neuroses of contemporary American suburbia. Popular suburban comedies of recent years, ranging from Robert Zemeckis's Back to the Future films of the 1980s to Hugh Wilson's 1999 comedy Blast From the Past use a similar motif of time-travel to 1950 s suburbia as the source of their humor and light social commentary. In a quite different vein, Todd Haynes's current, acclaimed melodrama of 
suburban repression, Far From Heaven, continues the look back at 1950s suburbia. In fact, Haynes's film, the second remake done of Douglas Sirk's 1955 film All That Heaven Allows, most clearly suggests the prolonged cultural afterlife of the image of suburbia constructed during the postwar years. Meticulously recreating the look and feel not necessarily of 1950s suburbia, but rather of Sirk's depiction of 1950s suburbia, Haynes's film intentionally and self-referentially toys with distinctions between real and imagined history, highlighting the sense of suburbia as a culturally constructed environment. And if, as Jameson argues, nostalgia films on the whole train us to "consume the past in the form of glossy images" (287), then it is also worth noting that the nostalgia mode in these suburban films confirms the extent to which this terrain has been, since the postwar years, very much an imaged environment, a landscape of the mind.

The oddly trans-historical look at suburbia offered by these films also underscores how firmly the vexed cultural perception of the suburbs remains tied to visions of suburbia in post-World War II America. Hollywood's anachronistic vision in this regard stands as testament to the profound cultural influence of the suburban landscape in the postwar years: for the development and subsequent massive expansion-particularly in the years and decades following the end of World War II—of "suburbia" entailed the construction of not only a new kind of physical landscape, but new psychic and emotional landscapes as well. Always as much an idea as a reality, the landscape of American suburbia has become and remained something of a symbolic minefield, the mirror (or, perhaps better put, the picture window) through which middle-class American culture casts its uneasy reflective gaze upon itself. Mere mention of the word "suburbia," after all, will call to mind for most Americans a familiar string of images - the grid of identical houses on identical lots, the smoking barbecue, the swimming pool, etc.-loaded signifiers that, taken together, connote both the middle-class "American dream" as it was promulgated by and celebrated in popular culture in the postwar years and that dream's inverse: the vision of a homogenized, soulless, plastic landscape of tepid conformity, an alienating "noplace." That such images seem drawn from an increasingly distant past, with "suburbia" and "the "50s" occupying a shared space in the collective cultural imagination, is neither accident nor coincidence. As a culture we retain a detached view of suburban place, relegating to the past a psychologically troublesome landscape which is nonetheless increasingly the dominant terrain of the nation.

The persistence of a reductive, two-dimensional vision of suburbia reflects the extent to which this insurgent landscape became, in the postwar years, invested with fixed symbolic meanings. While the rapid development and spread of postwar suburbs was largely a matter of necessity, an inevitable response to a great demand for housing, nevertheless the timing of this phenomenon has symbolic merit as well. Arriving as it did in a period of economic optimism and celebratory nationalism, suburbanization constructed a new type of landscape, complete with its own set of symbols and iconography, which served as the visible manifestation of the American "way of life." That is, while the appearance of planned suburban developments, the Levittowns and their followers across the nation, may have in actual- 
ity been a matter of form following function-the identical houses on identical plots a result of the developers' having followed the quickest, easiest, and most profitable building methods - this new type of residential space quickly became the visual image of the typical, even stereotypical, "American Dream" itself. Various media of popular culture, especially television and popular magazines, contributed through their glowing images of suburban life to an emerging sense of the suburbs as the promised land of the American middle class.

To see this point, one need only consider the depictions of suburbia offered on popular television sitcoms in the late 1950s through early 1960s. Standing in for their real-life counterparts, the suburban communities pictured on such programs as Father Knows Best, Leave it to Beaver, and The Donna Reed Show provided American culture at large with what would become its prevailing vision of suburbia; centered on harmonious family and community life, such programs envisioned the suburbs as both an idealized and insular landscape. In this sense the fledgling medium of television helped to invest the emergent landscape of suburbia with what has turned out to be an incredibly durable symbolic meaning, one that retains

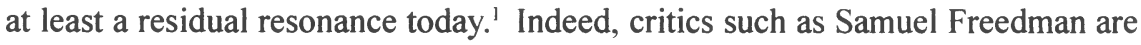
quite right in lamenting that popular culture continues to "peddle the same old cliché[d]" vision of suburbia as that offered on fifties television, often seeking out the "dark" underside of the televised image of suburbia as middle-class utopia in a reaction that has itself become all-too familiar, the dystopian view being yet another "clichéd" vision of suburban life (1). Freedman's apt observation reminds us of the pronounced and lasting power of fictive images in helping to shape our view of life in particular landscapes - a phenomenon that is most evident in the relationship between suburban life and its depiction on the small screen. That is, our continued cultural reliance on a restrictive, binary system in defining the suburban milieu reveals nothing so much as how televised images of suburbia formed an integral part of what Albert Hunter has termed the "symbolic ecology" of this particular landscape, or the collection of "processes by which symbolic meanings of . . environment [are] developed" (199).

Even as postwar popular media strove to invest the suburban environment with utopian ideals of community and neighborliness, a number of social critics quickly began to decry the dystopian aspects of suburban existence. At the height of suburban development and expansion, a series of sociological works emerged which castigated the new suburbanites, their landscapes, and their ways of living. Such influential texts as David Riesman's The Lonely Crowd, William H. Whyte's The Organization Man, Paul Goodman's Growing Up Absurd, and Betty Friedan's The Feminine Mystique read the suburbs as, respectively, a hotbed of conformity; an emasculating, corporate environment; a breeding ground for misdirected and disaffected youth; and a psychologically disabling prison for women. Indeed, these works - considered alongside a string of sensationalistic, quasi-sociological novels chronicling the living hell of suburban existence, such as John Keats's The Crack in the Picture Window and John McPartland's No Down Payment-signaled a chorus of vehement reaction against the suburban environment, and their influence can still be felt in contemporary attitudes toward suburban life. Fueled 
by, among other things, cold-war era concerns over enforced conformity, these critiques saw the suburban endeavor as threatening to cherished ideals of individuality and self-determination. Typical in this regard is the analysis of architectural critic Ada Louise Huxtable, who in 1964 lamented the spread of "regimented hordes of split-levels lined up for miles in close, unlovely rows" (186), arguing that suburban developers were responsible for the "standardization of America on a surprisingly low level" (188). As reactions against what by some were perceived as the utopian possibilities of suburban life, these critiques of suburbia helped to contribute to the two-dimensional view of the suburbs that persists in the popular imagination to this day: viewed from the outset as either utopian models of community or dystopian landscapes of dispiriting homogeneity, suburbs remain a contested, if only superficially understood, terrain.

The recent hit film Pleasantville offers further evidence of the tendency toward exaggeration and hyperbole in the depiction of suburbia. Pleasantville presents a similar thematic message to The Truman Show, as its young protagonists David (Tobey Maguire) and his sister Jennifer (Reese Witherspoon) find themselves transported through their television set-qua-time machine back into the world of David's favorite 1950s TV sitcom, "Pleasantville." The film tracks the siblings' efforts to bring some "color" (both literal and figurative) into the black-and-white world of the 1950s suburb they find themselves in. Though they eventually succeed in breaking through the soulless conformity of Pleasantville (and the town's gradual awakening is rendered through a characteristically late-twentieth-century visual gesture, the colorization of a black-and-white text), the pair meet significant resistance from the local chamber of commerce - angry, reactionary men who engage in book burning and other acts of desecration meant to terrorize the newly transgressive citizens of Pleasantville into resuming their former conformist identities. As Freedman notes, "The World War II veterans who thronged to actual suburbs in the 1950s might quibble ever so slightly" with the Nazi-esque identity Ross ascribes to the town fathers of Pleasantville (26). But it is just such an overthe-top critique of programmatic social rigidity that unites Pleasantville with The Truman Show: in both films, the suburb is depicted less as a lived place than as a signifier of certain cooptive, even totalitarian impulses that lurk beneath the fabric of centrist, middle-class American culture. And yet the strong sociopolitical message that these two films share is compromised by their reliance on models of suburbia drawn from the two-dimensional imagery of 1950 s situation comedy. The fact that both films position their critiques of suburbia (and in a larger sense of American culture as a whole) through the medium of television suggests not only TV's lasting influence on our view of suburbia but also, ultimately, the desire to displace any serious consideration of the suburban milieu, to view it instead through the safe and ultimately reassuring lens of hyperbolic fantasy.

Films such as Pleasantville and The Truman Show may well suggest a renewed cultural interest, at the end of the twentieth century, in the physical and social landscape of suburbia; nevertheless, these films also represent a perpetuation of the two-dimensional view of suburban life that has characterized the domi- 
nant perception of suburbia over the course of the second half of the twentieth century. That is, while both films offer something of a corrective response to the fantasy vision of suburban community as it was envisioned in the situation comedies of the 1950s, the very fact that they both defer to the Father Knows Best image of suburbia in constructing their critiques suggests the continued cultural dominance of the televised image of suburbia from that bygone era. While The Truman Show envisions contemporary suburban life as a 1950s-style suburban sitcom rendered inescapable through modern technology of surveillance and entrapment, Pleasantville constructs a morality tale concerning the values of contemporary suburban America by holding that social landscape up against both the utopian and dystopian visions of suburbia (each hopelessly, if intentionally, exaggerated) which emerged in the 1950s. Together these films suggest how little our cultural vision of suburbia changed over the course of the century.

Even the more serious and nuanced works of fiction and film set in the suburbs over the past half-century have consistently emphasized the perils of the suburbanite's existence. From the postwar years onward, writers such as Sloan Wilson, Philip Roth, Richard Yates, and John Cheever made suburban alienation a significant theme in our literature; writers who followed them in ensuing decades, from John Updike to Gloria Naylor to Ann Beattie, would continue to dissect the dynamics of suburban disaffection on both the personal and political levels. Filmmakers as well have often turned an uneasy eye toward suburbia: as I have argued elsewhere, Frank Capra's It's a Wonderful Life, a film consistently misread as merely a sappy, overly-nostalgic paean to a bygone small-town America, emerged as a tellingly ambivalent look at the coming landscape of suburbia. Released shortly after the end of World War II and shortly before the founding of the first Levittown, in Long Island, Capra's film expresses a pronounced unease over the landscape of postwar America, ultimately embracing the suburbs as our new "small towns," but not without a good deal of hand wringing along the way. Subsequent Hollywood representations of the suburbs have generally picked up on the negative aspects of suburbia that Capra only hinted at: from Don Siegel's 1956 adaptation of Jack Finney's Invasion of the Body Snatchers, an allegorical rendering of postwar conformity, to Bryan Forbes's 1975 film adaptation of Ira Levin's suburban horror novel The Stepford Wives or Jonathan Kaplan's 1979 suburban youth-rebellion thriller Over the Edge to recent films, such as The Truman Show, Pleasantville, Todd Solondz's Happiness, and Mendes's American Beauty, filmmakers have turned out any number of jeremiads depicting suburbia as an entrapping and troubling landscape. Even lighter looks at suburbia, ranging from Mike Nichols's 1967 screen adaptation of Charles Webb's The Graduate to Joe Dante's 1989 Tom Hanks comedy vehicle The 'Burbs, play on the same dark visions of suburban malaise as the source of their humor. Irrespective of genre or historical time frame, Hollywood's verdict on suburbia remains remarkably consistent: it is a place that fosters widespread neuroses, creating frustrated and entrapped wives/mothers, ineffectual, emasculated husbands/fathers, and rebellious, directionless children. It is the flip side of Beaver Cleaver's Mayfield. 


\section{Meet the New 'Burbs}

As I hope to have briefly demonstrated, the thematic insights of Weir's contemporary suburban satire The Truman Show hardly mark the film as unique; on the contrary, suburban fiction and films on the whole have been remarkably preoccupied with the dystopian aspects of the suburban experience. What does mark the Truman Show as distinct, however, and what suggests it to be an interesting starting point for considering contemporary depictions of suburbia, is the extra-textual matter of its having been shot on location: the movie was filmed in Seaside, Florida, the crown-jewel of the contemporary "New Urbanism" architectural movement, a postsuburban, neo-traditional urban-design philosophy centered on planned communities and described by its leading practitioners as an antidote to suburban sprawl. The ironies abound: Weir's choice of the master-planned, presumably post-suburban Seaside as the physical setting to depict his make-believe suburban sitcom set, which in turn was meant to mirror old-fashioned American suburbia, suggests a metatextual commentary on neotraditionalism, nostalgia, and planned (or enforced) community that is potentially explosive, but accessible only to those viewers aware of Seaside's history and philosophy. In a broader sense, The Truman Show's Seaside locale suggests the convergence of contemporary and postwar visions of suburbia at the turn of the millennium and the end of America's suburban century. In that sense, this film serves as an apt starting point for looking at the state of suburbia - and its representations - at the beginning of the twenty-first century.

In many ways, The Truman Show is a movie very much of its times, as turn-ofthe-century America has continued to struggle with ever-expanding suburban growth, as well as the dubious legacies - physical, demographic, and philosophical—of a half-century's worth of massive suburbanization. Not coincidentally, Weir repeatedly draws from It's a Wonderful Life-sometimes subtly, other times directly and explicitly - as he relays the story of Truman Burbank. In self-consciously echoing Capra's proto-suburban fantasy of fifty years earlier, Weir seems to be inviting his audience to reassess Capra's look at the suburban future, in light of the ensuing half-century of suburbanization. That he ultimately glosses his suburban satire with layers of horror/fantasy-as did both Forbes (The Stepford Wives) and Ross (Pleasantville) - does not take away from the elements of the film that do resonate with contemporary suburban experience. In fact, in its emphasis-however heavyhanded - on control and imprisonment masquerading as old-time community, The Truman Show evokes the two latest (and among the most philosophically complex) movements in American suburbanization: the neo-traditional developments of the New Urbanists, as well as the rising popularity of the "gated community."

Both gated communities and New Urbanist neo-traditional developments stand as responses, in differing manners, to suburban sprawl, the filling up of the countryside with what recent anti-suburban observers have called "jive-plastic commuter tract home wastelands" (Kunstler 10) and "sea-to-sea parking lots" (Lazare 2). For developers and residents of gated communities, creating a separate, walledoff community space provides not only security but also a measure of cultural distinction from the surrounding populace. Of course, gated communities-which 
by the mid-1990s housed some 3 to 4 million Americans (Blakely and Snyder, "Fortress Communities")-also raise fundamental questions regarding the relationship between individual and society. ${ }^{2}$ Representing the ultimate in privatization, gated communities typically provide their own security, street maintenance, trash collection, and the like, thus establishing a degree of independence from the surrounding municipality. In return, homeowners' associations in gated communities reserve the right to divorce themselves entirely from the denizens of the world outside the gates. It is not difficult to read the rise of gated communities as representing the culmination of certain patterns in suburbanization from the postwar years onward: if one impetus for the move to the suburbs has always been "flight" from the travails of urban existence and escape into a safe haven of sorts, then the gated community is merely the logical extension of this ethos. Nonetheless, the hyperexclusivity of gated communities raises genuine social and even legal concerns; legal scholar David J. Kennedy has recently argued that the barring of public access to previously public roads raises concerns regarding freedoms of speech and assembly, and also raises the specter of "Jim Crow-type" enforced segregation of municipal spaces (771). On the other side of the coin, if fear of outsiders drives the building of walls around communities, it requires little foresight to see that the gated community ought to become, as New Urbanist Peter Calthorpe argues, a "self-fulfilling prophecy," as enforced isolation will breed yet more fear of the increasingly unknown outsiders (Next American Metropolis 37). As "landscapes of fear," in geographer Yi-Fu Tuan's phrasing, the oxymoronically labeled gated communities figure "community" through a system of locks, guards, and barricadesa vision eerily reminiscent of the philosophy of The Truman Show's evil mastermind, Christof.

As opposed to the privatizing drive of the gated community movement, for the New Urbanists community planning and design "must assert the importance of public over private values" (Bressi xxx). Leaders of the New Urbanist movement, such as Andres Duany and Elizabeth Plater-Zyberk, the design team who created Seaside, Florida, believe that a sense of community can be facilitated through architectural and landscape design. Specifically, Duany and Plater-Zyberk counter traditional suburbia's emphasis on private property with a focus on communal spaces: master-planned communities, such as Seaside and the Disney corporation's "company town" of Celebration, Florida, feature pedestrian-friendly streets oriented toward identifiable town centers that support both recreational and employment opportunities, thus offering at least the possibility of organic community building. For some critics, the New Urbanism holds the promise of righting the wrongs of suburbia while at last realizing the utopian dream of community that the suburbs once seemed to offer. Vincent Scully, for example, argues that Seaside has "succeeded, more fully than any other work of architecture in our time has done, in creating an image of community" (226). Others would counter that Scully's phrasing is all-too accurate, and that all that has been created in Seaside, the hometown of Truman Burbank, is just that: the "image of community."

Certainly, the New Urbanists are vulnerable to the charge, often made by their detractors, that they are guilty of a sort of design fanaticism, a naïve belief that 
managing such elements as architectural design, street orientation, and visual perspective will somehow inherently instill a sense of community. Tom Martinson, for example, balks at Duany and Plater-Zyberk's zeal for community-via-landscapedesign, suggesting that "[t]he notion that [the suburbanite] exists to docilely populate some gentry designer's stage set is simply beyond reality" (43). Martinson goes on to point out that, however lofty its original goals may have been, Seaside has "matured into a pretentious cartoon of its original small-town ideal" (149). More significantly, New Urbanism has also been challenged as being almost exclusively geared toward the bourgeoisie: though leaders of the movement argue passionately for the potential renewal of abandoned urban centers and decaying innerring suburbs through New Urbanist principles, the fact remains that the great majority of their major projects have been higher-end enclaves such as Seaside. As Andrew Ross argues, "New Urbanist towns are 'commentaries' on urban problems, they do not provide a solution to them" (317-318).

\section{The More Things Change...}

Ross's phrasing recalls a famous remark made a half-century earlier by Bill Levitt, head of the architectural firm of Levitt and Sons, designers of the Levittowns and the pioneering merchant builders of the postwar suburban boom. Questioned about his company's selective selling practices-Levitt and Sons would allow no homes in Levittown to be sold to African American families - Levitt opined: "As a company our position is simply this: we can solve a housing problem or we can try to solve a racial problem but we cannot combine the two" (qtd. in Halberstam 141). Levitt's hands-off stance toward larger social issues epitomized the escapist mentality of postwar suburbia, and the legacy of such a philosophy unfortunately seems to live on today, even in high-minded movements such as the New Urbanism. That is, until the New Urbanist movement succeeds in offering residential designs that are truly open to the urban working class, their project will continue to be seenfairly or not-as merely the latest spin on the tried and true formula of escapist suburbanization. This might be another way of saying that the more things change in suburbia, the more they stay the same.

Much the same might be said about our broader cultural perception of the suburbs: though suburbia itself has continued to evolve, its image both in the popular media and in scholarly discourse has remained relatively static. From what impulses does this broad cultural resistance to the landscape of suburbia spring? After all, given the density of suburbia's symbolic ecology, it remains surprising that, until quite recently, not only architectural but also cultural, literary, and film critics have paid very little attention to this landscape. As Catherine Jurca points out, while literary critics for decades have focused on the city as the "complex generative location of realism, modernism, and, more recently, ethnic and African American literatures," suburbia has remained essentially "uncharted literary territory" among such critics (4). Similarly, the suburbs have remained underrepresented in the increasingly popular theoretical study of place. While critical attention seems equally divided between the urban milieu favored by humanistic geogra- 
phers and postmodern place theorists and the rural/wild places studied by ecocritics, suburbia, with a few notable exceptions, has remained until quite recently a critically forgotten place. A number of titles published in the past few years, however, suggest that suburbia is once again becoming a subject of critical concern. Recent histories of suburbanization include Rosalyn Baxandall and Elizabeth Ewen's Picture Windows: How the Suburbs Happened and Ann Marie Cammarota's Pavements in the Garden; Lorraine Kenny's Daughters of Suburbia and Tom Martinson's American Dreamscape are among the recent ethnographic and cultural studies of suburbia; and two new critical works focus on narrative representations of suburbia-Lynn Spigel's Welcome to the Dreamhouse, a study of television's depiction of suburbia, and Jurca's White Diaspora, an excellent examination of the suburb in the early-twentieth-century novel.

While this very recent proliferation of critical interest in suburbia perhaps suggests the emergence of a cross-disciplinary movement in suburban studies (it seems the first time since the late 1950 s and early ' 60 s that suburbia has captured such broad-based critical attention), still one wonders why it took so long for critical interest in the suburbs to rekindle. Among fiction and film critics, ambivalence toward the suburban setting may well have been fueled by a perceived lack of serious fictional and cinematic works set in the suburbs. And this point has its merits: despite the important and still-undervalued suburban fiction of writers associated with The New Yorker magazine, including Cheever, Updike, and Beattie, the most predominant strain of suburban fiction over the past half-century has consisted of lightweight comedies of suburban manners. This breezy but forgettable "tradition" ranges from John Marquand's satirical country club sketches and Max Schulman's suburban spoofs of the 1950s to any number of recent titles that continue the surface-level satirizing of suburbia. Hollywood cinema has often produced similarly lightweight suburban satires, as any viewer of films such as The 'Burbs or Burt Kennedy's Suburban Commando knows well enough. To judge by this unchanging tradition of lightweight suburban satire, it would seem almost as if the suburb - a pre-planned, homogeneous, transparently symbolic place-was from the outset overdetermined with cultural meaning, a landscape so indelibly etched with the markers of white, middle-class, family-centered American life as to make serious critical reconsideration seem superfluous at best, if not downright repugnant.

This tendency toward uncritical assessments of the suburban landscape is a point D. J. Waldie captures in his recent work Holy Land: A Suburban Memoir, as he recounts an event of particular significance that transpired shortly after the founding of his postwar suburban town of Lakewood, California. In 1950, after the houses were built but before residents had moved in to Lakewood-to that point the largest pre-planned suburban development town in the nation-a photographer shot a series of stark, aerial photographs of the new landscape, capturing the discomforting vision of a terrain as desolate as it was orderly; his work, as Waldie notes, would retain symbolic resonance for generations to come: "Four of the young man's photographs became the definition of this suburb, and then of suburbs generally .... Architectural critics and urban theorists reprinted the photo- 
graphs in books with names like God's Own Junkyard. Forty years later, the same four photographs still stand for the place in which most of us live" (6). Waldie concludes that, in the half-century since the founding of Lakewood, those same theorists and critics have not "looked again" at Lakewood, instead accepting the implication raised by the aerial photographs of an unpopulated, meticulous terrain: that the suburban "grid, briefly empty of association, is just a pattern predicting itself" (6). This observation raises interesting issues related to the study of suburbia as a lived environment-for the suburb, at the beginning of the twenty-first century, is no longer an emergent environment "empty of association," but rather a fixture of American landscape and society. Indeed, suburbia has, over the past halfcentury, become the dominant landscape in the United States, and yet it remains, as Waldie suggests, an under-scrutinized terrain.

Taking Waldie's point a step further, one is tempted to ask what, if any, relevance the postwar view of suburbia as an American dystopia holds today. One would be hard pressed, after all, to find a suburban town in the early-twenty-firstcentury United States that resembles the faceless uniformity and austerity of Lakewood in 1950 or Levittown in 1947. Indeed, even Levittown doesn't look like "Levittown" anymore; after decades of residents' additions and personalizing alterations to the homes of this first mass-produced suburban town, few if any of the original Bill Levitt home designs remain in their original form. ${ }^{3}$ Given this "humanization" of a once forbidding landscape, and the continued demand for suburban housing that facilitates the ongoing growth of suburbia across the country, one would imagine that America would have, by this point, made peace with the suburbs. And yet this is not the case: sociologists, environmental critics, and laypersons (including established suburbanites) continue to decry the seemingly inexorable process of suburban "sprawl," rightly seeing in suburban expansion the loss of more elemental, natural terrain and the withering social and economic importance of the American city. Perhaps the suburb, then, is the environment we as a culture want even when we know it is not good for us. Or perhaps the very process of suburbanization amounts to an exercise in self-loathing, a point humorist P. J. O'Rourke broaches in the title of a recent essay: "I Hate the Suburbs-Sort of ... But What I Really Hate is Myself." Either way, such paradoxical relationships to lived place suggest that the suburb continues to reflect both the desires and fears of American culture at large.

\section{Mirror, Mirror: Suburbia as Heterotopia}

A useful tool toward overcoming binary modes of thinking about the suburban landscape may be found in Michel Foucault's notion of heterotopic spaces. As Foucault argues in his influential essay "Of Other Spaces," all societies create what he calls "heterotopias," places that in their very existence serve to mirror the culture at large. He describes the heterotopia as a "kind of effectively enacted utopia in which the real sites, all the other sites that can be found within the culture, are simultaneously represented, contested, and inverted," concluding that heterotopias are "absolutely different from all the sites that they reflect and speak about" 
(24). Thus seeing heterotopic places as "mirrors" to the society that produced them, Foucault suggests that such places create "a space that is other, another real space, as perfect, as meticulous, as well arranged as ours is messy, ill constructed, and jumbled" (26). Noting that a utopian ideal of achieving "human perfection" leads such places to be rigorously "regulated," Foucault describes heterotopias with phrasing that puts one in mind of the suburban landscape that emerged in the postwar years - a meticulous, ordered, regulatory environment. The appeal of seeing suburbs as heterotopic spaces is that Foucault's formulation allows a way out of the impasse of the utopia/dystopia binary that has characterized our perception of suburbia throughout the latter half of the twentieth century.

Considered as a kind of heterotopic "mirror" to mainstream American culture, the suburb instead emerges as a place that reflects both an idealized image of middleclass life and specific cultural anxieties about the very elements of society that threaten this image. Indeed, the notion of suburbia as an American heterotopia suggests long held utopian and dystopian views of suburban life to be really two sides of the same coin, evidence of our culture's uneasy relationship to a landscape that mirrors both the fantasies and the phobias of the culture at large. As the visions of suburbia offered by postwar social critics and novelists indicate, the fantasy image of the suburb as a place of prosperity and "community" was from the outset beset with numerous social concerns; over the ensuing decades of suburban expansion, fears over antagonistic class, gender, and race relationships have further complicated our cultural vision of suburbia. As the suburb gradually became the dominant landscape in the United States, it also began to reflect increasingly complex cultural concerns, mirroring the anxieties of the culture at large.

Characteristically, in suburban fiction and film, the heterotopic qualities of the suburban landscape emerge through an implied or direct contrast of suburbia with the urban or rural realms. In such proto-suburban novels as Sinclair Lewis's Babbitt or F. Scott Fitzgerald's The Great Gatsby, suburban or exurban enclaves are clearly juxtaposed to the urban centers and wild places they are in the process of supplanting. In Babbitt, the commuter suburb provides a residential haven free from the bustle of the city, though it proves to be an entrapping and unenlightening place that leaves the protagonist longing for more elemental terrains. In The Great Gatsby, upper-class exurban environments are presented as manufactured fantasy worlds of escape and pleasure, until they are eventually overrun by the spread of urban corruption and violence, leaving behind only the yearning for a vanishing natural landscape. In Capra's It's a Wonderful Life, the emerging suburb of Bailey Park is counterpoised against both the pastoral charms of old-fashioned Bedford Falls and the specter of grimy, seedy, urban Pottersville, the place it would have become were it not for the unwitting actions of the film's hero, George Bailey. In subsequent fiction and films chronicling suburban life-from John Cheever's or Richard Yates's stories of suburban ennui to films such as The Stepford Wives-the equation remains essentially the same: suburbia, the faux-pastoral environment, represents a post-urban stage in protagonists' lives, one in which the sought-after escape from the urban center devolves into an exercise in entrapment and alienation. 
But what happens to this equation when the relationships to both the countryside and the central city cease to be defining characteristics of suburban place? Without question, the ongoing process of suburbanization is rendering the rural sphere an ever more marginal environment. Perhaps a more telling development is that the role of suburbs as bedroom communities to larger urban centers is clearly on the wane: by the mid-1990s, suburb-to-suburb commutes accounted for up to $40 \%$ of total commutes in the United States, while the once traditional suburb-tocity commute accounted for only $20 \%$ of all such trips (Calthorpe, "The Region" xii). With the increasing decentralization of businesses and services has come the development of what have been called, variously, "centerless cities" (Jackson), "technoburbs" (Fishman), "edge cities" (Garreau), or "multinucleated metropolitan regions" (Gottdiener and Kephart): densely developed and populated "suburban" areas that feature sufficient employment opportunities - typically in industrial, technological, retail, and service sectors - to render the break from the city complete. Simply put, most suburbs no longer maintain a subordinate relationship to a central city, a fact that has led some commentators to question whether suburbs, in the strict definition of the term, really exist anymore. For example, Robert Fishman argues that the increasing decentralization of not only housing but also industry, services, and jobs represents "not the culmination of 200 years of history of suburbia, but rather its end. Indeed, this massive change is not suburbanization at all but the creation of a new kind of city, with principles that are directly opposed to the true suburb" (183).

This spatial development would seem to have far-reaching ramifications for the understanding of suburban place in contemporary America. For if the emergent suburbs of the postwar years threatened to homogenize American experience, their ties to distinct urban centers nonetheless suggested an enduring metropolitan and regional identity; by contrast, the autonomous "technoburbs" of today, free of regional, metropolitan associations, convey a heightened sense of cultural homogenization. The office parks, shopping malls, "Super Wal-Marts," and "Price Clubs" that share today's suburban space know no regional identification; they look the same in New Mexico as they do in New York. Assessing this lost "autonomy" of the suburban small town, Jameson correctly concludes that "[w]hat was once a separate point on the map has become an imperceptible thickening in a continuum of identical products and standardized spaces from coast to coast" (281). How does this phenomenon - a kind of corporate "suburbanization of America" - affect place identification in general and representations of the suburban landscape in particular?

A good place to look for an answer to this question might be in contemporary fiction and films that attempt to present a realistic depiction of the suburbanized landscape. In contrast to grand suburban allegories, such as Pleasantville or The Truman Show, any number of recent films use minimalistic detail to convey the sense of suburbia as an interchangeable anyplace. Consider, for example, the 1996 Richard Linklater film SubUrbia, in which strip mall and convenience store parking lots come to define the boundaries of both environment and experience for a group of young friends. Perpetually "hanging out" at the 7-11 parking lot, the youth of 
SubUrbia, in their utter lack of direction, are meant to be representative of a generation raised in a landscape flattened by an inexorable, desultory standardization. A similar evocation of placelessness in contemporary America can be found in the fiction of writers from what has come to be called the "New South." Arguably no region of the United States has witnessed the phenomenon of homogenizing suburbanization more fully than the South over the past half-century, and realist fiction from contemporary southern writers tends to reflect this fact. A case in point can be found in the work of Bobbie Ann Mason, who provides a particularly compelling example because of her close affiliation with The New Yorker magazine, long associated with suburban fiction. An inheritor of The New Yorker tradition of precise, ironic realism, Mason uses her keen eye for detail to capture a Southern landscape notable not for its regional qualities, but for its sense of placelessness. Though her stories typically are set in Kentucky, one has the sense that they could be taking place anywhere in "technoburb" America, filled as they are with references to Wal-Marts, strip malls, and nondescript housing developments. In a sense, Mason's brand of hyperrealism takes The New Yorker tradition of suburban fiction to its logical conclusion, her interchangeable fictional milieux emphasizing, above all, the homogenization of place and experience in contemporary America.

And perhaps this is the fate of suburban place: confirming the worst fears of postwar social critics, the suburbs may well be flattening the landscape of America, fostering homogeneity of experience through the "displacement" of place itself. Nevertheless, other contemporary chroniclers of the suburbs present a different picture, invoking history as the factor that saves the suburbs from the fate of placelessness. Waldie's compelling memoir, a pastiche of autobiography and environmental and community history, concludes by presenting suburban Lakewood, California, as more a sacred landscape than a profane one. Though tempered throughout by recognition of the shortcomings of this postwar suburb-a place of shoddy homes financed by dubious and restrictive selling practices-Waldie's Holy Land suggests the values that inhere to a generationally-rooted place, even if that place is a suburban development town. Jeffrey Eugenides's The Virgin Suicides, despite the mysterious sadness that drives it, casts a wistful glance back at American suburbia of the 1970s, as does Mark Salzman's recent memoir, Lost in Place: Growing Up Absurd in Suburbia. A similar fondness for the suburbs fuels Pam Conrad's Our House: The Stories of Levittown, a short-story sequence for children that relays the stories of children growing up in Levittown, from the postwar years through the 1990s. Like Waldie, Conrad suggests that, through the sheer passage of time and the development of community ties and place-associations, the postwar suburb has become what no Cold War-era commentator ever thought it would be: the American small town.

\section{Full Circle: "Looking Closer" at Suburbia}

In contrast to these visions of suburban community and continuity, the recent spate of successful and celebrated films chronicling contemporary suburban life tend to view the history of the suburbs in a different light. Both Pleasantville and 
The Truman Show eschew notions of generational ties in the suburbs, figuring suburban history instead as a compendium of social anxieties that have changed little over the past half-century. Hollywood's most recent look at contemporary suburbia, Mendes's American Beauty, also focuses on the darker side of the suburban experience, invoking essentially traditional, dated critiques of suburban life: both the presentation of the protagonist as a beleaguered, emasculated head of household and the publicizing of his illicit sexual desires have a distinctly postwar feel; the caricatured depiction of his wife as an aggressively driven real estate agent amounts to $1980 \mathrm{~s}$-style anti-feminist backlash passed off as contemporary satire; and the nod to sexual plurality in the suburbs offered through a positive depiction of the protagonists' gay neighbors is undercut by the conclusion of the film, in which another neighbor - a confused, closeted army colonel - shoots and kills the protagonist in a fit of rage and passion. But the most interesting - and perhaps most conflicted - aspect of American Beauty lies in its treatment of the suburban landscape. After the film completes its unqualified condemnation of suburbia, the narrator's final, posthumous voice-over exhorts viewers to "look closer" and find the beauty in life-even, one is led to believe, in so hideous and dispiriting an environment as the suburb.

Ultimately, American Beauty seems an appropriate summation of turn-of-thecentury American views of the suburban landscape. For though the film at times hints at embracing both the "family values" associated with suburban living since the postwar years and the cultural pluralism of fin de siècle America, it finally undercuts both of these visions, retreating into a caricature of suburban life as hyperbolic as any offered by postwar novelists and social commentators. Nevertheless, Mendes critiques the particular social woes of suburbia in decidedly contemporary terms, demonizing the suburbs as embodying the worst aspects of modern American culture--superficiality, violence, aggressive and unreflective professional striving, and the complete absence of abiding familial and community ties. Needless to say, Mendes's vision of the specific problems besetting contemporary suburbia (and America) is a far cry from that of the postwar social critics, but the difference between these views only underscores the extent to which the suburbs have, for half a century, served as a mirror to the fantasies and phobias of the culture at large. For all of its faults, American Beauty suggests through its broad social critique that the suburban question has become increasingly complex. Indeed, the film's dramatic, if often strained, look at suburbia as the backdrop for a host of contemporary social ills forcefully reminds us of what the suburb has by now become for most Americans - not an alien, nondescript "noplace" lurking on the margins of the landscape and the culture, but in fact someplace far more intimate, the most profound and vexing of all environments: home.

\section{Notes}

${ }^{1}$ For studies that trace the profound social impact suburban situation comedies of the fifties and sixties had on culture in their day and beyond, see Liebman; Heller; Spigel.

${ }^{2}$ For a fuller discussion of the impact of gated communities in the U.S., see Blakely and Snyder, Fortress America. 
${ }^{3}$ Margaret Marsh notes that museum curators have expressed interest in preserving a Levitt house as a cultural artifact, while conceding that they would first have to "strip away the "improvements" to restore it to its original state. Marsh concludes: "The middle-class residential suburb ... has become an historical artifact .... It is not farfetched to think that Levittown, or a community like it, might become the Colonial Williamsburg of the twentysecond century" (188).

\section{Works Cited}

All That Heaven Allows. Dir. Douglas Sirk. Universal, 1955.

American Beauty. Dir. Sam Mendes. DreamWorks SKG, 1999.

Back to the Future. Dir. Robert Zemeckis. Amblin/Universal, 1985.

Baxandall, Rosalyn, and Elizabeth Ewen. Picture Windows: How the Suburbs Happened.

New York: Basic Books, 2001.

Beuka, Robert. "Imagining the Postwar Small Town: Gender and the Politics of Landscape in It 's a Wonderful Life." The Journal of Film and Video 51 (Fall/Winter 1999/2000): 36-47.

Blakely, Edward J., and Mary Gail Snyder. Fortress America: Gated Communities in the United States. Washington, D.C.: Brookings Institution Press, 1997.

-. "Fortress Communities: The Walling and Gating of American Suburbs." Nation's Cities Weekly 2 Oct. 1995: $1+$.

Blast From the Past. Dir. Hugh Wilson. Forge/Midnight Sun/New Line, 1999.

Bressi, Todd W. "Planning the American Dream." Katz xxv-xlii.

The 'Burbs. Dir. Joe Dante. Imagine, 1989.

Calthorpe, Peter. The Next American Metropolis: Ecology, Community, and the American Dream. Princeton, NJ: Princeton Architectural Press, 1993.

-. "The Region." Katz xi-xv.

Cammarota, Ann Marie. Pavements in the Garden. Madison, WI: Fairleigh Dickinson, 2001.

Conrad, Pam. Our House: The Stories of Levittown. New York: Scholastic, 1995.

Dick, Philip K. Time Out of Joint. New York: Vintage Books, 1959.

Dixon, Terrell. "Inculcating Wilderness: Ecocomposition, Nature Writing, and the Regreening of the American Suburb." The Nature of Cities: Ecocriticism and Urban Enviroments. Ed. Michael Bennett and David W. Teague. Tucson, AZ: University of Arizona Press, 1999. 77-90.

Eugenides, Jeffrey. The Virgin Suicides. New York: Farrar, Straus \& Giroux, 1993.

Far From Heaven. Dir. Todd Haynes. Clear Blue Sky/John Wells/Killer Films/Section Eight/USA Films/Vulcan Productions, 2002.

Finney, Jack. The Body Snatchers. London: Eyre \& Spottiswoode, 1955.

Fishman, Robert. Bourgeois Utopias: The Rise and Fall of Suburbia. New York: Basic Books, 1987.

Fitzgerald, F. Scott. The Great Gatsby. New York: Scribner's, 1925.

Foucault, Michel. "Of Other Spaces.” Trans. Jay Miskowiec. Diacritics 16 (Spring 1986): 22-27.

Freedman, Samuel G "Suburbia Outgrows Its Image in the Arts." The New York Times 28 Feb. 1999, sec. 2: $1+$.

Friedman, Betty. The Feminine Mystique. New York: Dell, 1963.

Garreau, Joel. Edge City: Life on the New Frontier. New York: Doubleday, 1991.

Goodman, Paul. Growing Up Absurd. New York: Random House, 1960.

Gottdiener, Mark, and George Kephart. "The Multinucleated Metropolitan Region: A 
Comparative Analysis." Postsuburban California: The Transformation of Orange

County Since World War II. Ed. Rob Kling, Spencer Olin, and Mark Poster. Los

Angeles: University of California Press, 1991. 31-54.

The Graduate. Dir. Mike Nichols. Embassy Pictures, 1967.

Halberstam, David. The Fifties. New York: Fawcett Columbine, 1993.

Happiness. Dir. Todd Solondz. Good Machine/Killer Films, 1998.

Heller, Dana. Family Plots: The De-Oedipalization of Popular Culture. Philadelphia, PA: University of Pennsylvania Press, 1995.

Hunter, Albert. "The Symbolic Ecology of Suburbia." Neighborhood and Community Environments. Ed. Irwin Altman and Abraham Wandersman. New York: Plenium Press, 1987. 191-221.

Huxtable, Ada Louise. "An Alternative to 'Slurbs." Suburbia in Transition. Ed. Louis H.

Masottie and Jeffrey K. Hadden. New York: New Viewpoints, 1974. 185-191.

Invasion of the Body Snatchers. Dir. Don Siegel. Allied Artists, 1956.

It 's a Wonderful Life. Dir. Frank Capra. RKO, 1946.

Jackson, Kenneth. Crabgrass Frontier: The Suburbanization of the United States. New

York: Oxford University Press, 1985.

Jameson, Fredric. Postmodernism, or, the Cultural Logic of Late Capitalism. Durham, NC: Duke University Press, 1999.

Jurca, Catherine. White Diaspora: The Suburb and the Twentieth-Century American Novel. Princeton, NJ: Princeton University Press, 2001.

Katz, Peter, ed. The New Urbanism: Toward an Archi-tecture of Community. New York: McGraw-Hill, 1994.

Keats, John. The Crack in the Picture Window. Boston: Houghton Mifflin, 1957.

Kennedy, David J. "Residential Associations as State Actors: Regulating the Impact of Gated Communities on Nonmembers." Yale Law Journal 105 (Dec. 1995): 761-793.

Kenny, Lorraine. Daughters of Suburbia. New Brunswick, NJ: Rutgers University Press, 2000.

Kunstler, James Howard. The Geography of Nowhere: The Rise and Decline of America's Man-Made Landscape. New York: Simon \& Schuster, 1993.

Lazare, Daniel. America's Undeclared War: What's Killing Our Cities and How We Can Stop It. New York: Harcourt, 2001.

Levin, Ira. The Stepford Wives. London: Joseph, 1972.

Lewis, Sinclair. Babbitt. New York: Harcourt, Brace and Co., 1922.

Liebman, Nina. Living Room Lectures: The Fifties Family in Film and Television. Austin, TX: University of Texas Press, 1995.

Marsh, Margaret. Suburban Lives. New Brunswick, NJ: Rutgers University Press, 1990.

Martinson, Tom. American Dreamscape: The Pursuit of Happiness in Postwar Suburbia. New York: Carroll \& Graf, 2000.

McPartland, John. No Down Payment. New York: Simon \& Schuster, 1957.

O'Rourke, P. J. "I Hate the Suburbs-Sort of . . But What I Really Hate is Myself." Rolling Stone 30 Sep. 1999: 35+.

Over the Edge. Dir. Jonathan Kaplan. Orion, 1979.

Pleasantville. Dir. Gary Ross. Larger Than Life/New Line, 1998.

Riesman, David. The Lonely Crowd: A Study of the Changing American Character. New Haven, CT: Yale University Press, 1950.

Ross, Andrew. The Celebration Chronicles: Life, Liberty, and the Pursuit of Property Value in Disney's New Town. New York: Ballantine, 1999.

Salzman, Mark. Lost in Place: Growing Up Absurd in Suburbia. New York: Random House, 1995. 
Scully, Vincent. "The Architecture of Community." Katz 221-230.

Spigel, Lynn. Make Room For TV: Television and the Family Ideal in Postwar America. Chicago: University of Chicago Press, 1992.

- Welcome to the Dreamhouse: Popular Media and Postwar Suburbs. Durham, NC: Duke University Press, 2001.

The Stepford Wives. Dir. Bryan Forbes. Fadsin/Palomar Pictures, 1975.

Suburban Commando. Dir. Burt Kennedy. New Line, 1991.

SubUrbia. Dir. Richard Linklater. Castle Rock/Detour Film Production, 1996.

The Truman Show. Dir. Peter Weir. Paramount, 1998.

Tuan, Yi-Fu. Landscapes of Fear. Minneapolis, MN: University of Minnesota Press, 1979.

Waldie, D. J. Holy Land: A Suburban Memoir. New York: Norton, 1996.

Webb, Charles. The Graduate. New York: American Library, 1963.

Whyte, William H. The Organization Man. New York: Simon \& Schuster, 1956. 